\title{
ARAH KIBLAT DALAM SALAT: \\ MENYIKAPI PERBEDAAN ANTARA MAZHAB HANAFI DAN SYAFI'I
}

\section{QIBLA DIRECTION IN SALAT: RESPONDING TO THE DIFFERENCES BETWEEN HANAFI AND SHAFI'I SCHOOL}

\author{
Akhmad Hanafi Dain Yunta \\ Sekolah Tinggi Ilmu Islam dan Bahasa Arab (STIBA) Makassar \\ Email: ahmadhanafi@stiba.ac.id \\ Ahmad Syaripudin \\ Sekolah Tinggi Ilmu Islam dan Bahasa Arab (STIBA) Makassar \\ Email: ahmadsyaripudin@stiba.ac.id \\ Junaedi \\ Sekolah Tinggi Ilmu Islam dan Bahasa Arab (STIBA) Makassar \\ Email : junaedi@gmail.com
}

\begin{tabular}{|c|c|}
\hline Keywords : & ABSTRACT \\
\hline $\begin{array}{l}\text { Qibla Direction, 'Ain al- } \\
\text { Ka'bah, Jihat al-Ka'bah }\end{array}$ & $\begin{array}{l}\text { The purpose of this study is to find out the solutions that can be taken by } \\
\text { Muslims regarding the differences of opinion between the Hanafi School } \\
\text { and the Syafii School about the direction of Qibla which more or less } \\
\text { has an impact on Muslims, especially in Indonesia. In this study, to get } \\
\text { answers to the problems above, the author uses analytical descriptive } \\
\text { research or istinbät al-ahkām which focuses on the study of manuscripts } \\
\text { and texts, using historical approaches, and normative juridical. The } \\
\text { results of this study indicate that: Muslims who will carry out the } \\
\text { construction of mosques need to adjust the position of the Kaaba } \\
\text { appropriately by maximizing existing technology, so that there are no } \\
\text { disputes in the future. However, if the mosque has been built, and then it } \\
\text { is alleged that it deviated slightly from 'ain al-ka'bah, then there is no } \\
\text { need to cancel the ijtihad with a new ijtihad by tilting the rows, because } \\
\text { the prayers that are performed towards the Ka'bah are still valid, even } \\
\text { though they are not in the right direction. ain al-ka'bah, while tearing } \\
\text { down the mosque or tilting the saf, will only create new problems and be } \\
\text { very burdensome for the people. For people who pray alone, it is highly } \\
\text { recommended to face the Qiblah by aiming correctly at 'ain al-ka'bah as } \\
\text { much as possible without making it difficult for themselves. }\end{array}$ \\
\hline \multirow{2}{*}{$\begin{array}{l}\text { Kata kunci : } \\
\text { Arah Kiblat, 'Ain al-Ka'bah, } \\
\text { Jihat al-Ka'bah }\end{array}$} & ABSTRAK \\
\hline & $\begin{array}{l}\text { Tujuan penelitian ini adalah untuk mengetahui solusi yang bisa } \\
\text { ditempuh oleh kaum muslimin terkait perbedaan pendapat antara } \\
\text { Mazhab Hanafi dan Mazhab Syafii tentang arah kiblat yang sedikit } \\
\text { banyaknya berdampak pada kaum muslimin khususnya di Indonesia. } \\
\text { Untuk mendapatkan jawaban terhadap permasalahan tersebut, penulis } \\
\text { menggunakan jenis penelitian deskriptif analisis atau istinbăt al-ahkäm } \\
\text { yang berfokus pada studi naskah dan teks, dengan menggunakan metode } \\
\text { pendekatan sejarah, dan yuridis normatif. Hasil penelitian ini } \\
\text { menunjukkan bahwa kaum muslimin yang akan melakukan } \\
\text { pembangunan masjid perlu menyesuaikan posisi Kakbah secara tepat } \\
\text { dengan memaksimalkan teknologi yang ada, sehinggga tidak terjadi } \\
\text { perselisihan di kemudian hari. Akan tetapi, jika masjid telah dibangun, }\end{array}$ \\
\hline
\end{tabular}




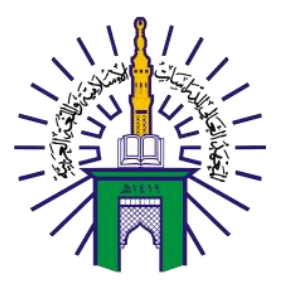

\section{BUSTANUL FUQAHA: \\ JURNAL BIDANG HUKUM ISLAM \\ Vol. 2 No. 3 (2021): Hal. 380-395 \\ EISSN: 2723-6021 \\ Website: https://journal.stiba.ac.id}

lalu disinyalir agak melenceng dari 'ain al-Ka'bah, maka tidak perlu
membatalkan ijtihad dengan ijtihad yang baru dengan cara memiringkan
saf, karena salat yang dilakukan mengarah Kakbah tetap sah, meskipun
tidak tepat mangarah 'ain al-Ka'bah, sementara merobohkan masjid atau
memiringkan saf, hanya akan membuat permasalahan baru dan sangat
memberatkan umat. Bagi orang yang salat sendirian sangat dianjurkan
untuk menghadap kiblat dengan mengarah secara tepat 'ain al-Ka'bah
semaksimal kemampuannya tanpa menyusahkan diri.

Diterima: 2 September 2021; Direvisi: 29 September 2021; Disetujui: 7 Oktober 2021; Tersedia online: 3 Desember 2021

How to cite: Akhmad Hanafi Dain Yunta, Ahmad Syaripudin, Junaedi, "Arah Kiblat dalam Salat: Menyikapi Perbedaan Antara Mazhab Hanafi dan Syafi'i”, BUSTANUL FUQAHA: Jurnal Bidang Hukum Islam Vol. 2, No. 3 (2021): 380-395. doi: 10.36701/bustanul.v2i3.404.

\section{PENDAHULUAN}

Dewasa ini permasalahan arah kiblat menjadi perbincangan yang serius, sehingga melahirkan ragam pendapat dan penafsiran di kalangan ulama. Memasuki abad ketiga para astronom muslim telah mulai merumuskan teori dan metode dalam menentukan arah kiblat, baik secara perhitungan maupun perkiraan alami. Upaya ini dilakukan pada kondisi daerah Arab yang diliputi oleh padang pasir yang sangan luas ${ }^{1}$. Sementara itu, Indonesia adalah negara bagian timur yang sangat berjauhan dengan dengan Kota Mekah. Indonesia dengan Mekah dibatasi oleh lautan dan daratan, sehingga tidak memungkinkan bagi kaum muslimin di Indonesia untuk melihat Kakbah secara langsung. Hal ini tentu mengundang pertanyaan, apakah masjid yang dibangun mengarah tepat ke Kakbah atau tidak.

Pada tahun 2010 salah satu TV swasta mewartakan bahwa terdapat 190.000 masjid di Indonesia yang arah kiblatnya tidak sesuai ${ }^{2}$. Sementara itu, Majelis Ulama Indonesia (MUI) dalam fatwanya No. 3 tahun 2010 menyatakan bahwa letak geografis Indonesia yang berada di bagian timur Kakbah atau Mekah, maka kiblat umat Islam Indonesia adalah menghadap ke arah barat, yang kemudian merekomendasikan bahwa bangunan masjid atau musala di Indonesia sepanjang kiblatnya menghadap ke barat, tidak perlu diubah, dibongkar, dan sebagainya ${ }^{3}$. Namun, fatwa ini kemudian direvisi, sebagaimana yang tercantum dalam fatwa No. 5 tahun 2010 yang menyatakan bahwa kiblat umat Islam Indonesia adalah menghadap ke barat laut dengan posisi bervariasi sesuai dengan letak kawasan masing-masing, yang kemudian merekomendasikan bahwa bangunan masjid atau musala yang tidak tetap arah kiblatnya, dan perlu ditata ulang safnya tanpa membongkar bangunannya ${ }^{4}$.

\footnotetext{
${ }^{1}$ Șafy al-Raḥmān Al-Mubārakfūrī, "Raḥ̄i Al-Makhtūm,” Cet. I (Beirūt: Dār al-Halāl, n.d.).

2 Arwin Juli Rakhmadi Butar-Butar, Kakbah Dan Problematika Arah Kiblat (Yogyakarta: Museum Astronomi Islam, 2013).

${ }^{3}$ Majelis Ulama Indonesia, Majelis Ulama Indonesia, Himpunan Fatwa Majelis Ulama Indonesia Sejak 1975 (Erlangga, n.d.).

${ }^{4}$ Ibid.
} 


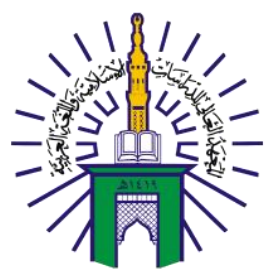

\section{BUSTANUL FUQAHA: \\ JURNAL BIDANG HUKUM ISLAM \\ Vol. 2 No. 3 (2021): Hal. 380-395 \\ EISSN: 2723-6021 \\ Website: https://journal.stiba.ac.id}

\section{BUSTANUL FUQAHA}

Jurnal Bidang Hukum Islam

Menyikapi fenomena tersebut sebagian masyarakat di beberapa tempat cenderung reaktif mengubah arah safnya dengan memiringkan sajadahnya. Bahkan ada yang sampai pada tataran membongkar masjid karena dinilai tidak tepat mengarah ke Kakbah. Pada tahun 2019, Kementerian Agama R.I. kembali mengajak umat Islam di Indonesia untuk mengecek kembali arah kiblat, tepatnya pada tanggal 27 dan 28 Mei 2019, karena pada waktu itu matahari berada di atas Kakbah ${ }^{5}$. Himbauan ini mengisyaratkan bahwa masjid yang tidak tepat mengarah ke kakbah, dianjurkan untuk memperbaiki atau menyesuaikannya dengan arah kiblat. Atas dasar fenomena keumatan tersebut, maka patut dilakukan pengkajian mendalam dalam menemukan pemecahan masalah dalam tinjauan fikih Islam. Namun, penulis membatasi pengkajian atas fenomena arah kiblat ini berdasarkan perspektif mazhab Hanafi dan mazhab Syafii.

Tujuan penelitian ini adalah untuk mengetahui solusi yang bisa ditempuh oleh kaum muslimin terkait perbedaan pendapat antara Mazhab Hanafi dan Mazhab Syafii tentang arah kiblat. Hal ini sedikit banyaknya berdampak pada kaum muslmin khususnya di Indonesia ihwal pemilihan pandangan yang bijak dari sudut pandang kedua mazhab besar tersebut. Sehingga, penulis menggunakan jenis penelitian deskriptif kualitatif dengan analisis konten atau istinbāt al-aḥkām yang berfokus pada studi naskah dan teks, dengan menggunakan metode pendekatan sejarah, dan yuridis normatif. Pendekatan sejarah dimaksudkan sebagai upaya pengkajian dalam menelaah sejarah peradaban Islam atau peristiwa penting yang pernah terjadi di masyarakat ${ }^{6789}$. Sementara pendekatan yuridis normatif dimaksudkan untuk mengkaji ihwal norma yang termuat dalam nas-nas dan pendapat para ulama atau imam mazhab serta peraturan yang ditetapkan oleh pemerintah.

Dari hasil penelusuran penulis, ditemukan beberapa penelitian terdahulu menyoal keabsahan salat, di antaranya: Pertama, penelitian yang berjudul, "Hukum Salat yang Tidak Sesuai Arah Kiblat: Studi Kasus Masjid-Masid Di Kecamatan Sidamanik." Hasil dari penelitian ini menyatakan bahwa masjid-masjid di Kecamatan Sidamanik setelah diteliti ternyata didapati bahwa kiblat masjid-masjid tersebut melenceng dan tidak tepat, dan melenceng hingga $23^{\circ}$, dan dari kenyataan ini mengingat menghadap kiblat termasuk syarat sah salat, maka salat yang dilaksanakan di masjid-masjid di Kecamatan Sidamanik tidak sah" ${ }^{10}$ Kedua, Penelitian yang berjudul, "Akurasi Arah Kiblat Masjid Di Ruang Publik." Hasil penelitian menunjukkan bahwa: 1) Pemahaman para pengelola

\footnotetext{
5 “Https://Bimasislam.Kemenag.Go.Id/Post/Berita/Ini-Waktu-Tepat-Cek-Arah-Kiblat (30,” n.d.

${ }^{6}$ Mukran H. Usman, Aswar Aswar, and Azwar Iskandar, "Menuju Indonesia Berkemajuan Dalam Studi Peradaban Islam" 21, no. 1 (2021): 39-74, doi:https://doi.org/10.24042/ajsk.v21i1.7862.

7 Mukran H. Usman, Azwar Iskandar, and Aswar Aswar, "Covid-19: Menguji Kebenaran Konspirasi Global," Jurnal Studi Agama Dan Masyarakat 16, no. 2 (2021): 122-31, doi:10.23971/jsam.v16i2.2238.

${ }^{8}$ Mukran H. Usman, Aswar Aswar, and Zulfiah Sam, "Covid-19 Dalam Perjalanan Akhir Zaman: Sebab, Dampak Dan Anjuran Syariat Dalam Menghadapinya," BUSTANUL FUQAHA: Jurnal Bidang Hukum Islam 1, no. 2 (2020): 137-55, doi:10.36701/bustanul.v1i2.142.

${ }^{9}$ Mukran H Usman and Aswar Aswar, "Korelasi Kehidupan Berislam Masyarakat Desa Baruga Dengan Kemakmuran, Keamanan Dan Ketentraman Hidup," Al-Din: Jurnal Dakwah Dan Sosial Keagamaan 6, no. 1 (2020): 1-14, doi:http://dx.doi.org/10.35673/ajdsk.v6i1.845.

${ }^{10}$ Rizki Muhammad Haris, "HUKUM SALAT YANG TIDAK SESUAI ARAH KIBLAT: Studi Kasus Masjid-Masjid Di Kecamatan Sidamanik," AT-TAFAHUM: Journal of Islamic Law 1, no. 1 (2017): 137.
} 


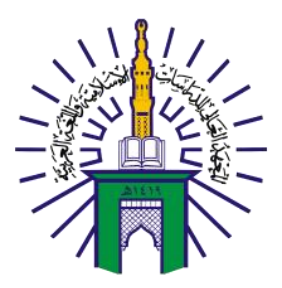

\section{BUSTANUL FUQAHA: \\ JURNAL BIDANG HUKUM ISLAM \\ Vol. 2 No. 3 (2021): Hal. 380-395 \\ EISSN: 2723-6021 \\ Website: https://journal.stiba.ac.id}

masjid di ruang publik pada tiga tempat tersebut mencerminkan kualitas hidup Islami yakni melakukan pengukuran kepada pihak ahli sehingga arah kiblat sesuai dengan keilmuan astronomi; 2) Akurasi atau ketelitian arah kiblat bangunan masjid di ruang publik di Sleman Yogyakarta termasuk dalam kategori akurat dengan alasan maksimal penyimpangan 6 menit busur, di mana arah penyimpangan paling besar pada masjidmasjid tersebut adalah $0^{\circ} 1^{\prime} 20,8^{\prime \prime}$ atau setara 3,074 $\mathrm{km}$ yang berarti masih mengarah Kota Mekah ${ }^{11}$.

Ketiga, penelitian yang berjudul, "Analisis Kontroversi dalam Penetapan Arah Kiblat Masjid Agung Demak." Hasil penelitian menunjukkan bahwa: 1) Argumentasi kelompok yang menghendaki pengubahan saf arah kiblat Masjid Agung Demak disesuaikan dengan hasil pengukuran ulang meliputi landasan Bayāni dan Burhāni, landasan Bayāni atau tekstual meliputi pendapat Syafi'iyah yang mengharuskan berupaya mencapai ain al-Ka'bah, meskipun letak Masjid Agung Demak jauh dari Kakbah di Makkah, kebolehan mengubah mihrab (hasil ijtihad) karena di kemudian hari ditemukan kesalahan, dan ijtihad yang baru tidak menghapus ijtihad lama yang lebih dahulu muncul, keduanya sama-sama eksis. Sedangkan argumentasi Burhāni meliputi keilmuan dan peralatan falak yang dipakai dalam mengukur arah kiblat Masjid Agung Demak; 2) Argumentasi kelompok yang menghendaki saf arah kiblat Masjid Agung Demak dikembalikan seperti semula mencakup landasan Bayāni dan 'Irfāni. Landasan Bayāni meliputi pendapat mayoritas ulama yang membolehkan cukup jihat al-Ka'bah bila lokasinya jauh dari Kakbah di Makkah, larangan mengubah mihrab yang telah ditetapkan 'alim, dan ijtihad tidak bisa dihapus dengan ijtihad baru. Sedangkan 'Irfāni mencakup penerimaan terhadap penetapan arah kiblat berdasarkan pengetahun ilham Sunan Kalijaga; 3) Mitologi Masjid Agung Demak mencakup pemitosan kewalian terhadap Sunan Kalijaga. Hal itu dilakukan demi menjaga keutuhan umat yang telah tentram dengan mengamalkan tradisi yang ditinggalkan Sunan Kalijaga. ${ }^{12}$

\section{PEMBAHASAN}

\section{Konsep Dasar Arah Kiblat}

Di antara syarat sahnya salat adalah menghadap kiblat, ${ }^{13}$ dasar perintah menghadap kiblat adalah firman Allah swt. dalam Qs. al-Baqarah/2:144,

Terjemahnya:

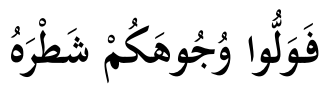

Maka palingkanlah mukamu ke arah Masjidil Haram. dan di mana saja kamu berada $^{14}$.

${ }^{11}$ Anisah Budiwati, “Akurasi Arah Kiblat Masjid Di Ruang Publik,” JSSH (Jurnal Sains Sosial Dan Humaniora) 2, no. 1 (2018): 159, doi:10.30595/jssh.v2i1.2275.

12 Ahmad Munif, "Analisis Kontroversi Dalam Penetapan Arah Kiblat Masjid Agung Demak" (IAIN Walisongo, 2013).

${ }^{13}$ Aḥmad ibn al-Husain Al-Aṣfahān̄̄, Matan Gāyah Al - Tagrīb, Cet. II (Dār al-Hijrah, 2016).

${ }^{14}$ Kementerian Agama RI, Alquran Dan Terjemahannya.Pdf, n.d. 


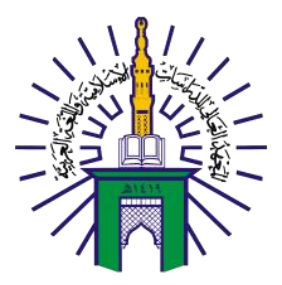

\section{BUSTANUL FUQAHA: \\ JURNAL BIDANG HUKUM ISLAM \\ Vol. 2 No. 3 (2021): Hal. 380-395 \\ EISSN: 2723-6021 \\ Website: https://journal.stiba.ac.id}

Maksudnya adalah sisi Masjil Haram. Dasar pengambilan hukumnya adalah terdapat pada kalimat.

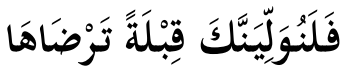

Terjemahnya:

Maka palingkanlah wajah ke kiblat yang sukai ${ }^{15}$.

Kemudian setelah turunnya ayat ini, Nabi Muhammad saw. diperintahkan untuk menghadap Masjidil Haram. ${ }^{16}$ Secara bahasa القبلة berarti ${ }^{17}$ yang bermakna arah. Kiblat juga bermakna نَاحيَة الصَّلَاة yang bermakna arah salat. Secara istilah kiblat adalah apa yang seseorang salat mengarah kepadanya dari bumi yang ketujuh sampai langit yang ketujuh yang sesuai dengan arah Kakbah. ${ }^{19}$ Dalam perkembangannya kiblat lebih sering diartikan sebagai Kakbah. Kakbah sendiri berasal dari bahasa Arab الكعبة yang artinya semua bangunan yang berbentuk segi empat. ${ }^{20}$

\section{Arah Kiblat Menurut Mazhab Hanafi}

Dalam permasalahan menghadap kiblat, mushalli tidak terlepas dari dua keadaan, keadaan mampu menghadap kiblat dan tidak mampu menghadap kiblat.

\section{Musalli (orang yang sedang salat) Mampu Mengahadap Kiblat}

Orang yang berada dalam Ka'bah, maka boleh baginya salat pada salah satu bagian dari Ka'bah baik salat sunah maupun salat wajib. ${ }^{21}$ Sebagaimana hadis yang diriwayatkan oleh sahabat Abdullah ibn Umar ra. dia berkata:

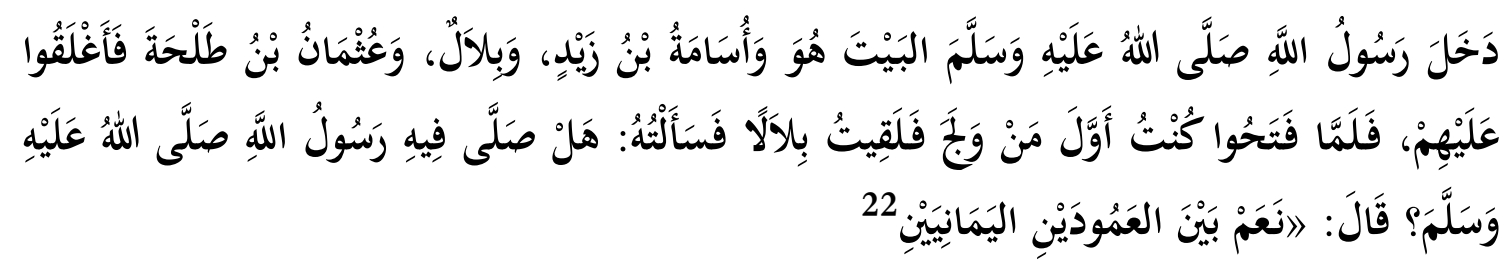

Artinya:

Nabi Muhammad saw. bersama Usāmah ibn Zaid, Bilāl dan Uṡmān ibn Ṭalhah masuk ke dalam Ka'bah maka saya menutup pintunya. Tatkala mereka membuka pintunya mak saya adalah orang yang pertama masuk maka saya

\footnotetext{
15 Ibid.

${ }^{16}$ Muḥammad ibn Muḥammad al-Rūmī, “Al-'Ināyah Syarh Al-Hidāyah” (Dār al-Fikr, n.d.).

${ }^{17}$ Sa'dī Abu Habīb, Al-Qamūs Al-Fiqh Lugah Wa Iștilāh, Cet. II (Damaskus: Dār al-Fikr, 1988).

18 'Alī ibn Ismā'īl Al-Mursī, "Al-Muḥkam Al-Muḥị̣ Al- A'ẓam,” Cet.I (Dār al-Kutub al'Alamiyyah, 2000).

${ }_{19}$ Ayyūb ibn Mūsā al-Ḥanafī, "Al-Kalimāt Mu’jam Fī Al-Muṣṭalahạat Wa Al-Furūq AlLugawiyyah" (Beirūt: Muassasah al-Risālah, n.d.).

${ }^{20}$ Abu Habīb, Al-Qamūs Al-Fiqh Lugah Wa Iștilāh.

${ }^{21}$ Muḥammad ibn Aḥmad al-Sarkhasī, “Al-Mabsūṭ” (Bairūt: Dār al-Ma’rifah, 1993).

${ }^{22}$ Muḥammad ibn Ismā'̄̄l ibn Ibrāhīm Al-Bukhārī, Șahīh Al-Bukhārī, Cet. I (al-Qāhirah: Dār ibn al-Jauzī, 2010).
} 


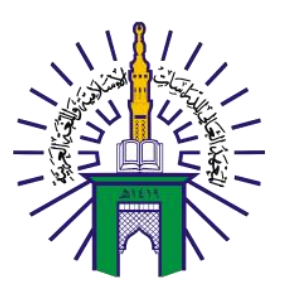

\section{BUSTANUL FUQAHA: \\ JURNAL BIDANG HUKUM ISLAM \\ Vol. 2 No. 3 (2021): Hal. 380-395 \\ EISSN: 2723-6021 \\ Website: https://journal.stiba.ac.id}

mendapati Bilāl dan bertanya: “Apakah Nabi Muhammad saw. salat di dalam?”, dia menjawab "iya, diantara dua tiang Kakbah.

Adapun orang yang berada di luar Ka'bah dan berada di sisi Ka'bah, maka wajib menghadap ain al-ka'bah dan tidak diperbolehkan menghindar atau berbelok dari Ka'bah meskipun sedikit saja. Bagi orang yang berada di kota Mekah maka wajib menghadap ain al-ka'bah karena Nabi Muhammad di Masjidil Haram menghadap ke Ka'bah. Dan setelah itu diikuti oleh para sahabat dan orang yang setelahnya, maka hal tersebut sudah menjadi ijmak. Adapun jika seseorang tidak bisa melihat Ka'bah maka wajib baginya menghadap arah Ka'bah karena Allah swt. memerintahkan Nabi Muhammad saw. dan para sahabat menghadap ke Masjidil Haram sementara beliau saw. berada di Madinah. ${ }^{23}$

\section{Orang Tidak Mampu Menghadap Kiblat}

Seseorang yang tidak mampu menghadap kiblat juga terbagi dua yaitu seorang yang tidak bisa menghadap kiblat karena adanya uzur sementara ia mengetahui arah kiblat, maka boleh banginya salat ke arah yang dia mampu, dan kewajiban menghadap kiblat gugur darinya, seperti orang yang berada dalam ketakutan, atau orang sakit, dan tidak bisa menghadap kiblat sementara tidak ada yang bisa mengarahkannya ke arah kiblat, dan yang lainnya. Keadaan seperti ini dibolehkan untuk tidak menghadap kiblat karena ini adalah syarat tambahan maka kewajibannya gugur ketika ada uzur.

Kedua seseorang yang memang tidak mampu menghadap kiblat karena dia ragu keberadaan kiblat seperti orang yang berada di padang pasir, di kegelapan malam, atau orang tidak memiliki alat untuk mengetahui keberadaan kiblat, maka ia harus bertanya kepada orang lain mengenai keberadaan Ka'bah dan tidak boleh berijtihad. Namun, jika ia melakukannya dan posisinya benar mengarah Ka'bah maka salat sah, akan tetapi jika salah maka salatnya batal. ${ }^{24} \mathrm{Al}$-Kasān̄i mengatakan, seorang yang tidak menemukan orang lain untuk bertanya, maka boleh dia berijtihad terhadap posisi kiblat, karena beban syariat berdasarkan situasi dan kondisi sementara ia tidak memiliki pilihan lain kecuali berijtihad saja, maka boleh baginya salat dengan berijtihad. ${ }^{25}$ Dan kewajibannya hanya menghadap arah saja. ${ }^{26}$ Allah swt. berfirman dalam Qs. al-Baqarah/2: 115.

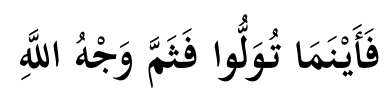

Terjemahnya:

Maka di mana saja kamu menghadapkan wajahmu maka di sana ada wajah Allah. $^{27}$

\footnotetext{
${ }^{23}$ al-Rūmī, "Al-'Ināyah Syarh Al-Hidāyah."

${ }^{24}$ Abu Bakar ibn Mas'ūd al-Kasānī, "Badāi’ Al-Șanāi’ Fi Tartīb Al- Syarāi’” (Dār al-'Alamiyyah, 1986).

25 Ibid.

${ }^{26}$ Muḥammad ibn Abī Bakar al-Ḥanafī, "Tuḥfah Al-Mamlūk,” Cet. I (Beirūt: Dār al-Basyāir alIslāmiyyah, n.d.).

${ }^{27}$ Kementrian Agama RI, Al-Qur'an Dan Terjemahnya (Jakarta Timur: Ummul Qura, 2018).
} 


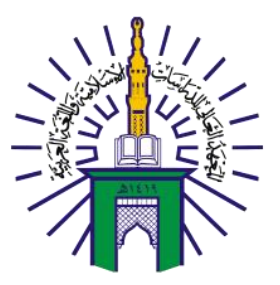

\section{BUSTANUL FUQAHA: \\ JURNAL BIDANG HUKUM ISLAM \\ Vol. 2 No. 3 (2021): Hal. 380-395 \\ EISSN: 2723-6021 \\ Website: https://journal.stiba.ac.id}

Ulama mazhab nanafiyah beristidlal dengan dalil dalil berikut bahwah musalli yang yang jauh dari Ka'bah hanya berkewajiban untuk mengarah saja, bukan menghadap ke 'ain Kabah, antara lain:

a. Al-Qur'an

Firman Allah swt. dalam Qs. al-Baqarah/2: 144.

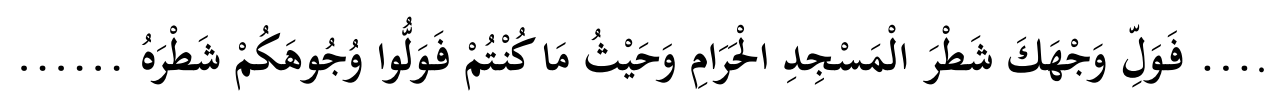

Terjemahnya:

....Palingkanlah mukamu ke arah Masjidil Haram. dan dimana saja kamu berada, Palingkanlah mukamu ke arahnya....... ${ }^{28}$

Aḥmad ibn Mūsā al-Ḥanafĩ berkata bahwa, Kata syatrah dalam ayat ini bermakna arah. $^{29}$

b. Hadis

Nabi Muhammad saw. bersabda

$$
30 \text { مَا بَيْنَ الْمَشْرِقِ وَالْمَغْرِبِ قِبْلَةُ (رواه الترمذِي) }
$$

Artinya:

Arah antara timur dan barat adalah kiblat.

\section{Arah Kiblat Menurut Mazhab Syafii}

Menurut Mazhab Syafii menghadap kiblat adalah syarat sahnya salat kecuali pada dua keadaan, keadaan sebagaimana firman Allah swt. dalam Qs. al-Baqarah/2:144,

Terjemahnya:

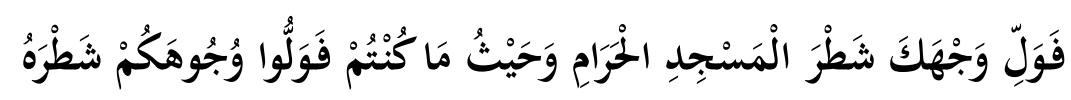

Maka Palingkanlah mukamu ke arah Masjidil Haram dan di mana saja kamu berada, Palingkanlah mukamu ke arahnya ${ }^{31}$.

Adapun yang dimaksudkan Masjidil Haram dalam ayat ini adalah bangunan Kakbah. Sedangkan yang dimaksudkan syatrah di sini adalah arah Kakbah dan semisalnya. Penyebutan Masjidil Haram memiliki berapa makna antara lain:

\section{Kakbah}

Firman Allah swt. dalam Qs. al-Baqarah/2:144,

${ }^{28}$ Ibid.

29 Aḥmad ibn Mūsā Al-Ḥanafī, Al-Bināyah Syarḥ Al-Hidāyah, Cet. I (Bairūt: Dār al-Kutub al'Alamiyyah, 2000).

${ }^{30}$ Muḥammad ibn 'Īsā Al-Tirmidż̀i, "Sunan Al-Tirmiżì," Cet. II (Mesir: Syarikah Maktabah wa Maṭba’ah Musțafā al-Bābī al-Ḥalabī, 1973).

${ }^{31} \mathrm{RI}$, Al-Qur'an Dan Terjemahnya. 


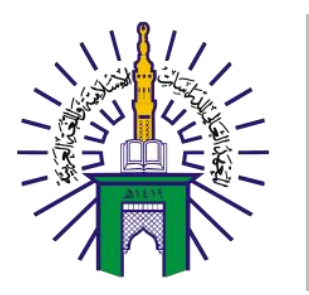

\section{BUSTANUL FUQAHA: \\ JURNAL BIDANG HUKUM ISLAM \\ Vol. 2 No. 3 (2021): Hal. 380-395 \\ EISSN: 2723-6021 \\ Website: https://journal.stiba.ac.id}

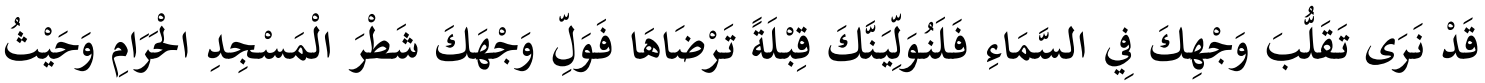

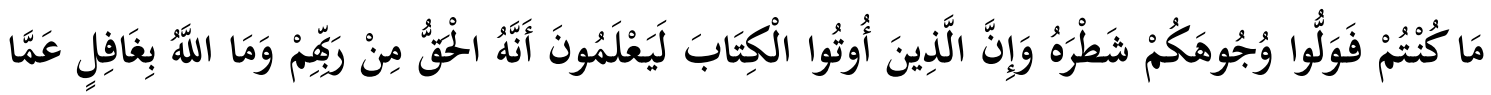 يَعْمَلُونَ}

Terjemahnya:

Sungguh Kami (sering) melihat mukamu menengadah ke langit, maka sungguh Kami akan memalingkan kamu ke kiblat yang kamu sukai. Palingkanlah mukamu ke arah Masjidil Haram dan di mana saja kamu berada, Palingkanlah mukamu ke arahnya dan sesungguhnya orang-orang (Yahudi dan Nasrani) yang diberi Alkitab (Taurat dan Injil) memang mengetahui, bahwa berpaling ke Masjidil Haram itu adalah benar dari Tuhannya dan Allah sekali-kali tidak lengah dari apa yang mereka kerjakan. ${ }^{32}$

\section{Masjidil Haram dan Sekitarnya}

Sabda Nabi Muhammad saw. yang berbunyi,

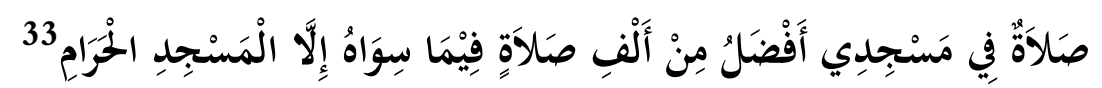

Artinya:

Salat di masjidku (Masjid Nabawi) lebih utama daripada 1000 salat di masjid lainnya kecuali Masjidil Haram.

Dan sabda Nabi Muhammad saw. yang berbunyi,

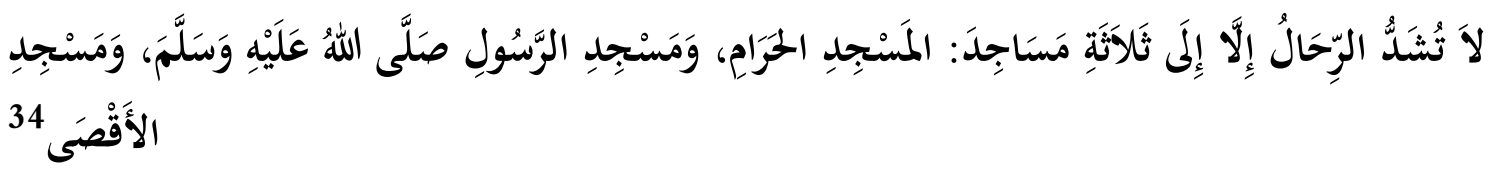

Artinya:

Janganlah bersengaja melakukan perjalanan (dalam rangka ibadah dan tujuan safarnya adalah tempatnya) kecuali pada tiga masjid, Masjidil Haram, Masjid Nabawi dan Masjidil Aqsa.

\section{Mekah Semua}

Firman Allah swt. dalam Qs. al-Baqarah/2:196,

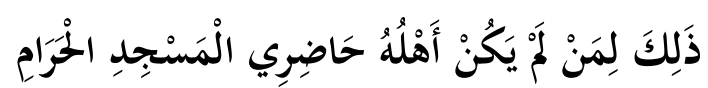

Terjemahnya:

\footnotetext{
32 Ibid.

${ }^{33}$ Muḥammad ibn Yazīd Ibn Mājah, "Sunan Ibn Mājah” (Dār Iḥya' al-Kutub al-“Arabiyyah, n.d.).

${ }^{34}$ Al-Bukhārī, Șahīh Al-Bukhārī.
} 


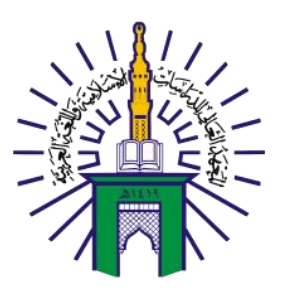

\section{BUSTANUL FUQAHA: \\ JURNAL BIDANG HUKUM ISLAM \\ Vol. 2 No. 3 (2021): Hal. 380-395 \\ EISSN: 2723-6021 \\ Website: https://journal.stiba.ac.id}

Demikian itu (kewajiban membayar fidyah) bagi orang-orang yang keluarganya tidak berada (di sekitar) Masjidil Haram (orang-orang yang bukan penduduk Kota Mekah

\section{Mekah dan Daerah Haram ${ }^{35}$}

Firman Allah swt. dalam Qs. at-Taubah/9:28,

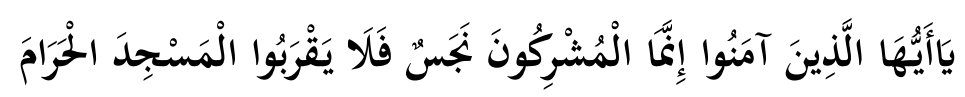

Terjemahnya:

Hai orang-orang yang beriman, sesungguhnya orang-orang yang musyrik itu najis, maka janganlah mereka mendekati Masjidil haram. ${ }^{36}$

Menurut Imam Syafii menghadap kiblat itu ada dua macam, bagi orang yang mampu melihat Kakbah seperti orang-orang yang berada di Masjidil Haram, di rumah, tempat yang datar, gunung, maka tidak boleh salat kecuali harus menghadap ain al-Ka'bah karena dia mampu untuk menghadap 'ainul ka'bah. Jika seseorang buta maka dia harus minta orang lain untuk menghadapkannya ke Kakbah. Jika ia tidak menemukan orang yang bisa mengarahkannya ke Kakbah maka dia salat dan wajib mengulangi salatnya karena dia tidak mengetahui bahwa dia salat menghadap kiblat tatkala ia tidak menggunakan petunjuk yang Allah swt. ciptakan seperti matahari, bulan, gunung, angin dan yang lainnya, yang biasa dijadikan oleh orang yang ahli terhadap arah untuk mengetahui posisi Kakbah.

Bagi orang yang bisa melihat, jika salat di kegelapan malam, maka dia harus berijtihad tentang posisi Kakbah lalu salat, jika dia mengetahui bahwa dia salah maka wajib baginya mengulangi salatnya sebagai bentuk kehati-hatian. Bagi orang yang buta, kemudian ada orang yang menghadapkannya ke kiblat kemudian dia salat, namun dia mendapatkan berita yang lebih kuat bahwa dia tidak menghadap kiblat maka ia harus mengulangi salatnya. Adapun jika seseorang salat di dalam sebuah ruangan tanpa melihat Kakbah namun ia tepat menghadap kiblat atau seorang yang buta kemudian keduanya ragu bahwa mereka telah salah dalam mengadap kiblat maka tidak perlu mengulang salat. Hal ini karena tidak melihat Kakbah kecuali mereka mengetahui bahwa mereka telah salah dalam menghadap kiblat maka harus mengulang salat.

Bagi orang yang berada di Mekah dan tidak melihat Kakbah atau di luar Kota Mekah, ketika ingin melaksanakan salat tidak boleh baginya meninggalkan ijtihad untuk menghadap ain al-Ka'bah dengan petunjuk yang dapat mengarahkannya ke ain alKa'bah seperti bintang, matahari, bulan, arah angin, dan apa saja yang dapat menunjukkannya pada kiblat. Adapun seseorang yang berada di luar Mekah maka harus berijtihad tentang posisi kiblat ${ }^{37}$ karena Imam Syafii mengharuskan menghadap ain al$K a$ 'bah secara perkiraan yang $\mathrm{kuat}^{38}$.

\footnotetext{
${ }^{35}$ Yahyā ibn Syaraf al-Nawawī, “Al-Majmū’ Syarh Al-Muhażżab” (Dār al-Fikr, n.d.).

${ }^{36} \mathrm{RI}$, Al-Qur'an Dan Terjemahnya.

${ }^{37}$ Muhạmmad ibn Idrīs al-Syāfi'‘̄, “Al-Umm” (Beirūt: Dār al-Ma’rifah, 1990).

38 Aḥmad Salāmah dkk al-Qalyūbī, "Hāāsyiyā Qalyūbī Wa 'Umairah” (Beirūt: Dār al-Fikr, 1995).
} 


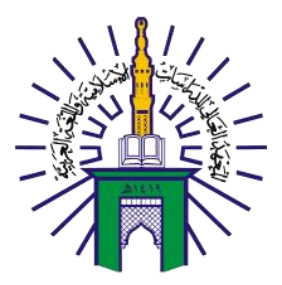

\section{BUSTANUL FUQAHA: \\ JURNAL BIDANG HUKUM ISLAM \\ Vol. 2 No. 3 (2021): Hal. 380-395 \\ EISSN: 2723-6021 \\ Website: https://journal.stiba.ac.id}

Imam al-Māwardī menegaskan bahwa Imam Syafii berpendapat bahwa bagi orang yang jauh dari Mekah yang tidak melihat Kakbah maka wajib berijtihad untuk menghadap ain al-Ka'bah karena ijtihad kepada ain al-Ka'bah akan mengantarkannya pada keyakinan ${ }^{39}$. Adapun pendapat beliau juga diikuti oleh orang-orang setelah beliau dari mazhab Syafii bahwa yang benar dalam mazhab Syafii adalah menghadap ainul $K a{ }^{\prime} b a h^{40}$.

Dasar hukum mazhab Syafii tentang kewajiban menghadap ain al-Ka'bah secara dugaan yang sangat kuat ketika jauh dari kota Mekah antara lain:

a. Al-Qur'an

Firman Allah swt. dalam Qs. al-Baqarah/2:144,

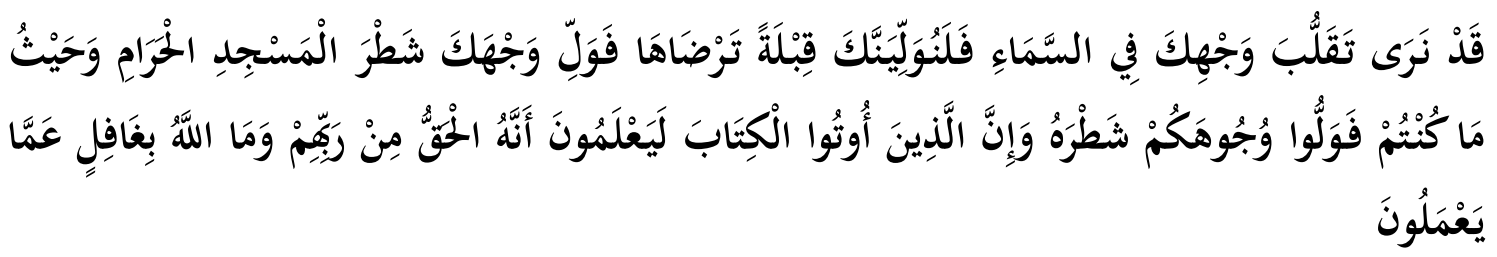

Terjemahnya:

Sungguh Kami (sering) melihat mukamu menengadah ke langit, maka sungguh Kami akan memalingkan kamu ke kiblat yang kamu sukai. Palingkanlah mukamu ke arah Masjidil Haram, dan di mana saja kamu berada, Palingkanlah mukamu ke arahnya, dan sesungguhnya orang-orang (Yahudi dan Nasrani) yang diberi Alkitab (Taurat dan Injil) memang mengetahui, bahwa berpaling ke Masjidil Haram itu adalah benar dari Tuhannya dan Allah sekali-kali tidak lengah dari apa yang mereka kerjakan ${ }^{41}$.

Menurut imam Syafii kata syatrah dalam ayat ini bermakna ain al-ka'bah karena secara bahasa asal kata syatrah bermakna 'ain. ${ }^{42}$

b. Hadis

Hadis Nabi Muhammad saw. sebagaimana yang diriwayatkan sahabat Ibnu Abbas, beliau berkata:

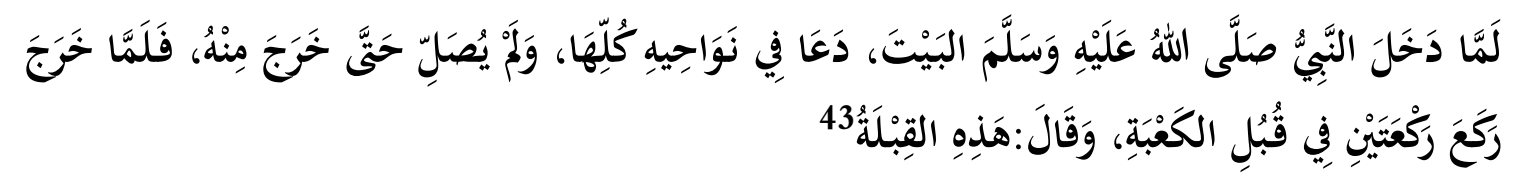

Artinya: 1999

39 'Alī ibn Muhammad al-Māwardī, "Al-Ḥāwī Al-Kabīr Fī Al-Fiqh Mazhab Al-Imām Al-Syāfi'̄̄i,"

${ }^{40}$ al-Nawawī, "Al-Majmū' Syarh Al-Muhażżab."

${ }^{41}$ RI, Al-Qur'an Dan Terjemahnya.

${ }^{42}$ al-Qalyūbīin, "Hāsasyiyā Qalyūbī Wa 'Umairah."

${ }^{43}$ Al-Bukhārī, Șahīh Al-Bukhārī. 


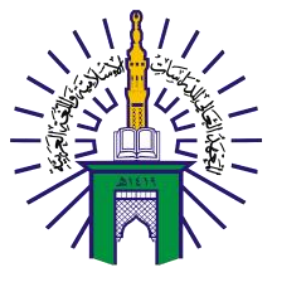

\section{BUSTANUL FUQAHA: \\ JURNAL BIDANG HUKUM ISLAM \\ Vol. 2 No. 3 (2021): Hal. 380-395 \\ EISSN: 2723-6021 \\ Website: https://journal.stiba.ac.id}

Ketika Nabi Muhammad saw. masuk ke dalam Kakbah, beliau berdoa di semua sisi Kakbah, dan beliau saw. tidak melaksanakan salat sampai beliau saw. keluar dari Kakbah, maka tatkala beliau saw. keluar beliau salat 2 rakaat di sisi Kakbah dan berkata: "Ini adalah kiblat".

Kata kiblat dalam hadis maksudnya adalah $\mathrm{Kakbah}^{44}$. Secara singkat perbedaan antara Mazhab Syafii dan Mazhab Hanafi dalam masalah arah kiblat dapat dilihat pada tabel berikut:

Tabel 1. Perbandingan Posisi Muṣallī Antara Mazhab Hanafi dan Mazhab Syafi'i

\begin{tabular}{llllll}
\hline No & Posisi Musholli & Mazhab Hanafi & Mazhab Syafii & \\
\hline 1. & $\begin{array}{l}\text { Di dalam bangunan } \\
\text { Kakbah }\end{array}$ & $\begin{array}{l}\text { Berdiri pada salah satu bagian } \\
\text { Kakbah }\end{array}$ & $\begin{array}{l}\text { Berdiri pada salah satu bagian } \\
\text { Kakbah }\end{array}$ \\
\hline 2. & Di dekat Kakbah & Wajib menghadap ain al-Ka'bah & $\begin{array}{l}\text { Wajib menghadap ain al- } \\
\text { Ka'bah }\end{array}$ \\
\hline 3. & Di Kota Makkah & Wajib menghadap ain al-Ka'bah & $\begin{array}{l}\text { Wajib menghadap ain al- } \\
\text { Ka'bah }\end{array}$ \\
\hline 4. & Di Luar Kota Makkah & Wajib menghadap arah Kakbah & $\begin{array}{l}\text { Wajib berijtihad untuk } \\
\text { menghadap ain al-Ka'bah }\end{array}$ \\
\hline
\end{tabular}

Dari tabel di atas, tampak bahwa perbedaan Mazhab Hanafi dan Mazhab Syafii tentang arah kiblat, hanya pada masalah muṣalli yang sangat jauh dari Kakbah.

\section{Analisis Komparasi Mazhab Hanafi dan Mazhab Syafii tentang Arah Kiblat}

Ihwal komparasi pendapat Mazhab Hanafi dan Mazhab Syafii tentang arah kiblat, penulis cenderung untuk mengkompromikan kedua pendapat tersebut. Khusunya, bagi kaum muslimin yang sangat jauh dari Kakbah, dengan cara berijtihad semaksimal kemampuan kita untuk mengarah ke Kakbah meskipun besar kemungkinan melenceng dari 'ainul Ka'bah. Kaum muslimin tidak perlu menyusahkan diri, atau berdebat tentang arah kiblat atau mengulangi salat berdasarkan sangkaan tentang arah kiblat.

Orang yang berada di luar Kota Mekah kewajibannya hanya berusaha untuk menghadap arah kiblat bukan dituntut untuk menghadap 'ainul Ka'bah. Adapun landasan pemikiran penulis antara lain: Pertama, perbuatan sahabat Nabi Muhammad saw. ketika mereka sedang melakukan salat Subuh di Quba dalam keadaan masih menghadap ke Baitul Maqdis di Syam dan tiba-tiba datang seseorang yang memberitahukan bahwa arah kiblat telah dipalingkan maka para sahabat langsung berbalik arah dari Syam menuju Makkah tanpa mencari secara persis ain al-Ka'bah karena menetapkan ain al-Ka'bah harus menggunakan ilmu ukur.

Kejadian ini sebagaimana hadis yaang diceritakan sahabat Ibnu umar ra. beliau berkata:

${ }^{44}$ Sa'dī Abu Habīb, Al-Fiqh Al-Manhajī F̄̄ Mazhab Al-Imām Al-Syāfi 'ī, Cet. II (Damaskus: Dār al-Fikr, 1988). 


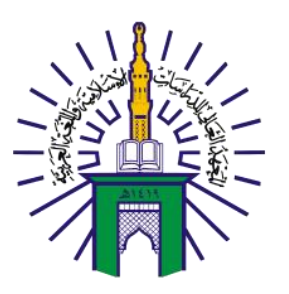

\section{BUSTANUL FUQAHA: \\ JURNAL BIDANG HUKUM ISLAM \\ Vol. 2 No. 3 (2021): Hal. 380-395 \\ EISSN: 2723-6021 \\ Website: https://journal.stiba.ac.id}

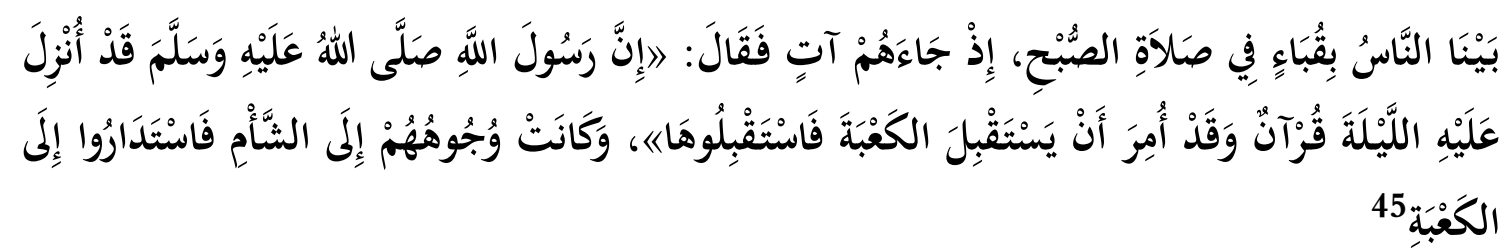

Artinya:

Di mana ketika orang-orang melaksanakan salat Subuh di Quba kemudian datang seseorang dan berkata: "Sesungguhnya Nabi Muhammad saw. telah diberi wahyu tadi malam dan beliau saw. telah diperintahkan untuk menghadap Kakbah maka menghadaplah kalian ke Kakbah. Sedang waktu itu mereka menghadap Syam kemudian mereka berputar ke arah Kakbah."

Perbuatan sahabat ini menunjukkan bahwa kita hanya diperintahkan untuk berijtihad untuk menentukan arah Kakbah lalu menghadap kearahnya dalam salat, sekiranya harus pas menghadap 'ainul Ka'bah dan batal salatnya jika melenceng maka berpaling dari arah Baitul Maqdis ke arah Kakbah sia-sia, karena jika melenceng sedikit saja, maka sama saja jika mereka tetap menghadap ke Baitul Maqdis.

Kedua, sabda Nabi Muhammad saw. yang berbunyi:

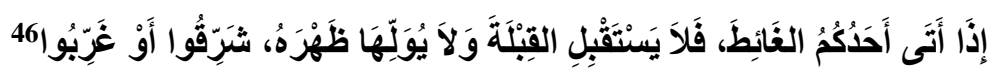

Artinya:

Jika salah seorang di antara kalian mendatangi tempat buang air maka janganlah dia menghadap kiblat dan tidak pula punggungnya membelakanginya tetapi menghadaplah ke timur atau ke barat.

Hadis di atas menunjukan bahwa semua arah antara timur dan barat adalah kiblat bagi penduduk Madinah. ${ }^{47}$

Memaksudkan ain al-Ka'bah sebagai tujuan kiblat adalah sesuatu yang sangat memberatkan. Padahal Allah swt. berfirman dalam Qs. al-Maidah/5:6,

Terjemahnya:

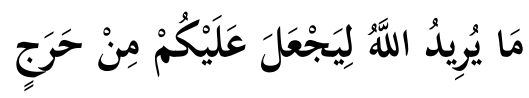

Allah tidak hendak menyulitkan kamu ${ }^{48}$.

\footnotetext{
45 Al-Bukhārī, Șahīh Al-Bukhārī.

46 Ibid.

47 Kamāl ibn al-Sayyid Sālim, "Șaḥị̣ Fiqh Al-Sunnah Wa Adillatuh Wa Tauḍ̄ị Mażāhib AlAimmah" (al-Qāhirah: al-Maktabah al-Tauqīfiyyah, 2003).

${ }^{48} \mathrm{RI}$, Al-Qur'an Dan Terjemahnya.
} 


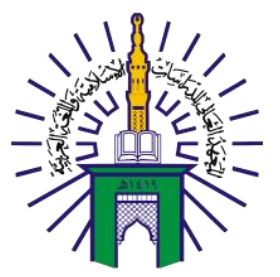

\section{BUSTANUL FUQAHA: \\ JURNAL BIDANG HUKUM ISLAM \\ Vol. 2 No. 3 (2021): Hal. 380-395 \\ EISSN: 2723-6021 \\ Website: https://journal.stiba.ac.id}

Hal ini di karenakan menentukan ain al-Ka'bah tidak bisa dilakukan kecuali dengan pendekatan ilmu ukur maka bagaimana mungkin seseorang bisa menentukan ain alKa'bah hanya dengan cara ijtihad, sementara kaum muslimin tidak dibebankan untuk berjitihad dengan menggunakan ilmu ukur yang merupakan alat untuk mengutur panjang lebarnya sebuah negeri. ${ }^{49}$

Dalil Aqli, pada jarak yang dekat dari Kota Mekah mengarahkannya ke ain al$K a$ 'bah itu terasa sulit lalu bagaimana lagi bagi orang yang jauh dari Kota Makkah yang berada di ujung barat dan ujung timur. Seandainya menghadap ke arah ain al-Ka'bah itu wajib, maka tidak ada seorang pun yang salatnya sah karena mustahil bagi seseorang yang berada di ujung timur dan barat bisa memposisikan jarak yang lebih dari 20 hasta dari Kakbah maka sudah seharusnya menghadap ke arah Kakbah dan bukan 'ainul $K a$ 'bah, dan umat sepakat sahnya salat menghadap arah Kakbah. Dilihat dari sisi lain, Para sahabat di zaman Nabi Muhammad saw. tidak mendatangkan ahli di bidang pengukuran ketika akan membangun masjid, meluruskan mihrab, sementara untuk menentukan ain al-Ka'bah harus menggunakan ilmu ukur, dan tidak ada ulama yang mengatakan bahwa belajar tentang ilmu ukur hukumnya wajib ${ }^{50}$.

Dahulu para sahabat ketika menaklukkan negeri-negeri, mereka membangun masjid-masjid yang disesuaikan dengan arah kiblat tanpa menyesuaikan garis yang sejajar dengan posisi ain al-Ka'bah sebagaimana yang telah diketahui oleh para ahli dalam masalah arah, dan mereka salat di dalamnya dan orang-orang setelahnya sepakat bolehnya salat di dalamnya ${ }^{51}$.

Ukuran Kakbah hanya berkisar kurang lebih $10 \times 10^{52}$ meter, sementara ukuran masjid yang ada rata-rata lebih besar dari ukuran Kakbah. Itu menunjukkan bahwa kebanyakan orang salat tidak mengahadap 'ainul Ka'bah, tetapi menghadap arah Kakbah meskipun posisi masjid secara ilmu ukur sejajar dengan bangun Kakbah, lalu bagaimana dengan masjid yang memang tidak mengarah secara tepat ke bangunan Kakbah maka sudah dapat dipastikan bahwa orang yang salat di dalamnya tidak menghadap ain al-Ka'bah sebagaimana ilustrasi berikut.

\footnotetext{
${ }^{49}$ Ibn Rusyd al-Qurtubī, "Bidāyah Al-Mujtahid Wa Nihāyah Al-Muqtașid," Cet. I (al-Qāhirah: Dār al-Salām, 2016).

50 Muḥammad 'Alī Al-Ṣābūn̄̄, "Rawāi' Al-Bayān Tafsīr Āyāt Al-Aḥkām,” Cet. II (Damaskus: Maktabah al-Gazālī, 1980).

51 'Abd al-Raḥmān ibn Aḥmad ibn Rajab al-Ḥanbalī, "Fatḥ Al-Bārī Syarḥ Șahị̣̄ Al-Bukhārī," Cet. I (al-Madinah al-Nabawiyyah: Maktabagh al-Gurabā' al-Aśariyyah, 1996).

52 Al-Mubārakfūrī, "Rahị̄ Al-Makhtūm."
} 

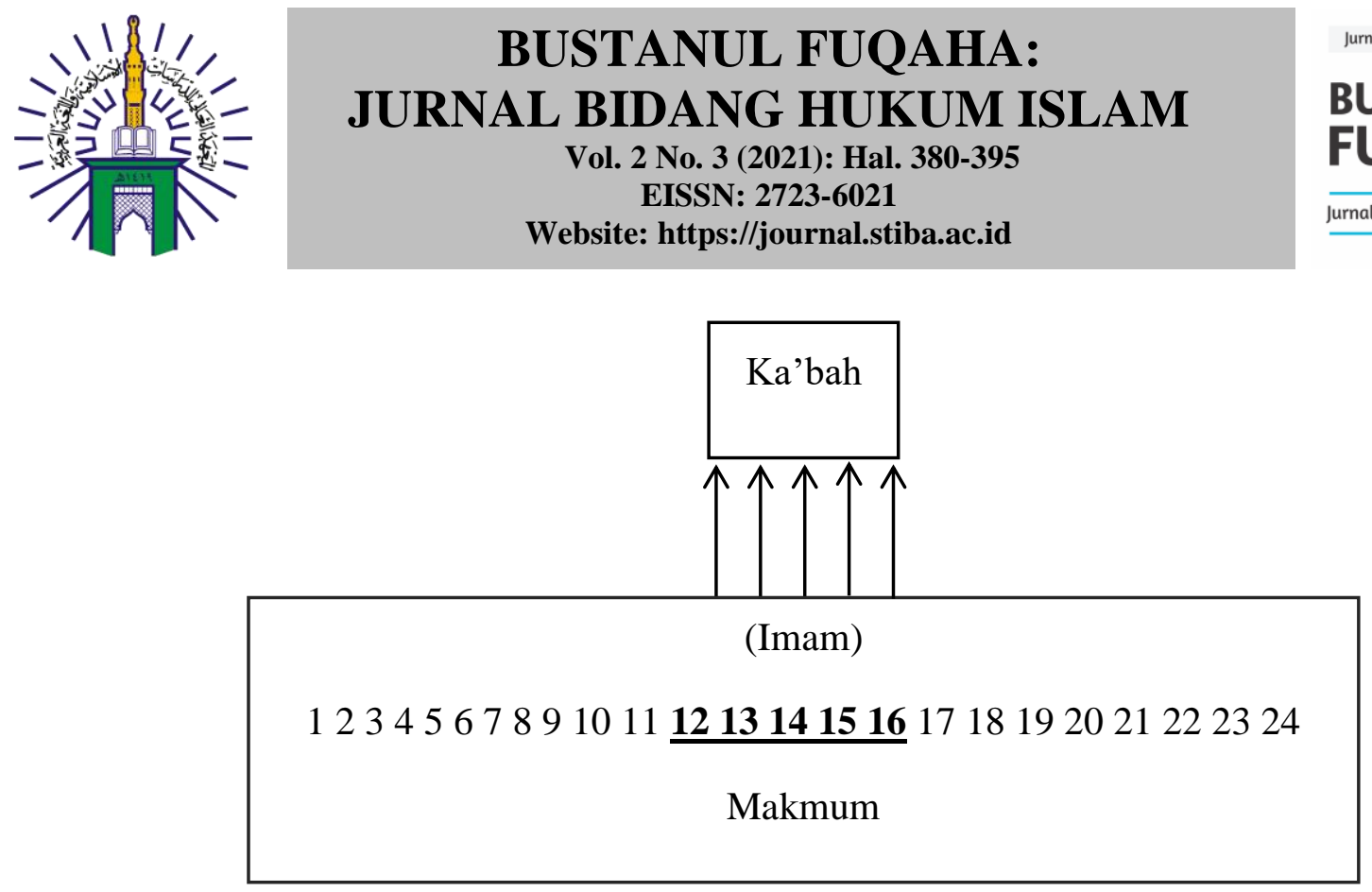

Gambar 1. Posisi Imam dan Makmum Menghadap Kiblat dalam Salat

Ibnu Rajab rahimahullah mengatakan bahwa para ulama telah sepakat bahwa saf yang sangat panjang yang letaknya jauh dari Kakbah dinyatakan sah. Padahal telah diketahui bahwa tidak mungkin semuanya menghadap ke bangunan Kakbah dari sisi ketika seseorang keluar dari garis lurus yang sejajar dengan Kakbah, maka pasti garis itu akan mengalami kemiringan meskipun sedikit sehingga semakin bertambah jauh suatu daerah maka kemiringan garis itu juga akan semakin bertambah ${ }^{53}$. Selain itu, Imam al-Azra' $\overline{1}$ berkata: Sebagian sahabat Imam Syafii mengatakan mustahil bagi penduduk (yang jauh dari Kakbah) untuk menghadap 'ainul Ka'bah, karena Kakbah itu kecil, maka cukup menghadap ke arah Kakbah, oleh karena itu sah salat dengan saf yang panjang ketika jauh dari Kakbah dan pendapat ini sesuai dengan pendapat imam Abu Hanifah. ${ }^{54}$

\section{KESIMPULAN}

Penelitian ini adalah untuk mengetahui solusi yang bisa ditempuh oleh kaum muslimin terkait perbedaan pendapat antara Mazhab Hanafi dan Mazhab Syafii tentang arah kiblat, yang sedikit banyaknya berdampak pada kaum muslmin khususnya di Indonesia. Hasil penelitian ini menunjukkan bahwa kaum muslimin yang akan melakukan pembangunan masjid perlu menyesuaikan posisi Kakbah secara tepat dengan memaksimalkan teknologi yang ada, sehinggga tidak terjadi perselisihan di kemudian hari. Akan tetapi, jika masjid telah dibangun, lalu disinyalir agak melenceng dari 'ainul Ka'bah, maka tidak perlu memiringkan saf, karena salat yang dilakukan mengarah Kakbah tetap sah, meskipun tidak tepat mangarah 'ainul Ka'bah, sementara merobohkan masjid atau memiringkan saf, hanya akan membuat permasalahan baru dan sangat memberatkan umat. Bagi orang yang salat sendirian sangat dianjurkan untuk menghadap kiblat dengan mengarah secara tepat 'ainul $\mathrm{Ka}$ 'bah, semaksimal kemampuannya tanpa menyusahkan diri.

\footnotetext{
53 al-Ḥanbalī, "Fatḥ Al-Bārī Syarḥ Șaḥịh Al-Bukhārī."

${ }^{54}$ Abd al-Raḥmān Muhammad, Bugyah Al-Mustsyrisdī̄n (Beirūt: Dār al-Fikr, 1994).
} 


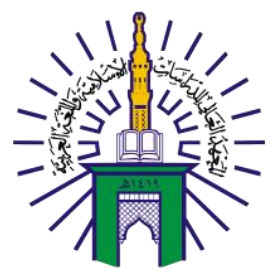

\section{BUSTANUL FUQAHA: \\ JURNAL BIDANG HUKUM ISLAM \\ Vol. 2 No. 3 (2021): Hal. 380-395 \\ EISSN: 2723-6021 \\ Website: https://journal.stiba.ac.id}

\section{DAFTAR PUSTAKA}

RI, Kementrian Agama. Al-Qur'an Dan Terjemahnya. Jakarta Timur: Ummul Qura, 2018.

Abu Habīb, Sa'dī. Al-Fiqh Al-Manhajī F̄̄ Mazhab Al-Imām Al-Syāfi'̄̄. Cet. II. Damaskus: Dār al-Fikr, 1988.

_. Al-Qamūs Al-Fiqh Lugah Wa Iștilāah. Cet. II. Damaskus: Dār al-Fikr, 1988.

Al-Aṣfahānī, Aḥmad ibn al-Husain. Matan Gāyah Al - Tagrīb. Cet. II. Dār al-Hijrah, 2016.

Al-Bukhārī, Muḥammad ibn Ismā’̄̄l ibn Ibrāhīm. Șah̄̄h Al-Bukhārī. Cet. I. al-Qāhirah: Dār ibn al-Jauzī, 2010.

Al-Ḥanafī, Aḥmad ibn Mūsā. Al-Bināyah Syarḥ Al-Hidāyah. Cet. I. Bairūt: Dār alKutub al-'Alamiyyah, 2000.

al-Ḥanafī, Ayyūb ibn Mūsā. "Al-Kalimāt Mu’jam F̄̄ Al-Muṣṭalaḥāt Wa Al-Furūq AlLugawiyyah.” Beirūt: Muassasah al-Risālah, n.d.

al-Ḥanafī, Muḥammad ibn Abī Bakar. "Tuḥfah Al-Mamlūk," Cet. I. Beirūt: Dār alBasyāir al-Islāmiyyah, n.d.

al-Ḥanbalī, 'Abd al-Raḥmān ibn Aḥmad ibn Rajab. "Fatḥ Al-Bārī Syarḥ Șaḥị̣ AlBukhārī," Cet. I. al-Madinah al-Nabawiyyah: Maktabagh al-Gurabā' alAsariyyah, 1996.

al-Kasān̄̄, Abu Bakar ibn Mas'ūd. "Badāi' Al-Șanāi’ Fi Tartīb Al- Syarāi'.” Dār al'Alamiyyah, 1986.

al-Māwardī, 'Alī ibn Muhammad. "Al-Ḥāwī Al-Kabīr F̄i Al-Fiqh Mazhab Al-Imām AlSyāfi'’̄,' 1999.

Al-Mubārakfūrī, Șafy al-Raḥmān. "Raḥīq Al-Makhtūm," Cet. I. Beirūt: Dār al-Halāl, n.d.

Al-Mursī, 'Alī ibn Ismā’̄̄l. “Al-Muḥkam Al-Muhịị Al- A’ẓam,” Cet.I. Dār al-Kutub al'Alamiyyah, 2000.

al-Nawawī, Yahyā ibn Syaraf. “Al-Majmū' Syarh Al-Muhażżab.” Dār al-Fikr, n.d.

al-Qalyūbī, Aḥmad Salāmah dkk. "Hāāyiyā Qalyūbī Wa 'Umairah.” Beirūt: Dār al-Fikr, 1995.

al-Qurtub̄̄, Ibn Rusyd. "Bidāyah Al-Mujtahid Wa Nihāyah Al-Muqtașid," Cet. I. alQāhirah: Dār al-Salām, 2016.

al-Rūmī, Muhammad ibn Muhammad. "Al-'Ināyah Syarh Al-Hidāyah.” Dār al-Fikr, n.d.

Al-Ṣābūnī, Muḥammad 'Alī. "Rawāi' Al-Bayān Tafs̄ì Āyāt Al-Aḥkām," Cet. II. Damaskus: Maktabah al-Gazālī, 1980.

al-Sarkhasī, Muḥammad ibn Aḥmad. “Al-Mabsūṭ.” Bairūt: Dār al-Ma'rifah, 1993.

al-Syāfí'̄, Muhammad ibn Idrīs. “Al-Umm.” Beirūt: Dār al-Ma'rifah, 1990.

Al-Tirmidżī, Muhammad ibn 'İsā. "Sunan Al-Tirmiżì," Cet. II. Mesir: Syarikah Maktabah wa Maṭba'ah Musțafā al-Bābī al-Halabī, 1973.

Budiwati, Anisah. "Akurasi Arah Kiblat Masjid Di Ruang Publik.” JSSH (Jurnal Sains Sosial Dan Humaniora) 2, no. 1 (2018): 159. doi:10.30595/jssh.v2i1.2275.

Butar-Butar, Arwin Juli Rakhmadi. Kakbah Dan Problematika Arah Kiblat. Yogyakarta: Museum Astronomi Islam, 2013. 


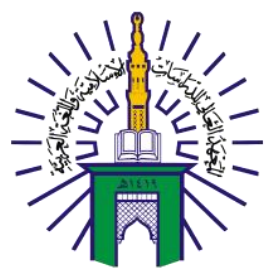

\section{BUSTANUL FUQAHA: \\ JURNAL BIDANG HUKUM ISLAM \\ Vol. 2 No. 3 (2021): Hal. 380-395 \\ EISSN: 2723-6021 \\ Website: https://journal.stiba.ac.id}

Haris, Rizki Muhammad. "HUKUM SALAT YANG TIDAK SESUAI ARAH KIBLAT: Studi Kasus Masjid-Masjid Di Kecamatan Sidamanik." $A T$ TAFAHUM: Journal of Islamic Law 1, no. 1 (2017): 137.

"Https://Bimasislam.Kemenag.Go.Id/Post/Berita/Ini-Waktu-Tepat-Cek-Arah-Kiblat (30," n.d.

Ibn Mājah, Muḥammad ibn Yazīd. "Sunan Ibn Mājah.” Dār Iḥya' al-Kutub al'Arabiyyah, n.d.

Majelis Ulama Indonesia. Majelis Ulama Indonesia, Himpunan Fatwa Majelis Ulama Indonesia Sejak 1975. Erlangga, n.d.

Muḥammad, Abd al-Raḥmān. Bugyah Al-Mustsyrisdī̄n. Beirūt: Dār al-Fikr, 1994.

Munif, Ahmad. "Analisis Kontroversi Dalam Penetapan Arah Kiblat Masjid Agung Demak." IAIN Walisongo, 2013.

RI, Kementerian Agama. Alquran Dan Terjemahannya.Pdf, n.d.

RI, Kementrian Agama. Al-Qur'an Dan Terjemahnya. Jakarta Timur: Ummul Qura, 2018.

Sālim, Kamāl ibn al-Sayyid. "Șaḥị̣ Fiqh Al-Sunnah Wa Adillatuh Wa Tauḍīh Mażāhib Al-Aimmah." al-Qāhirah: al-Maktabah al-Tauqīfiyyah, 2003.

Usman, Mukran H., Aswar Aswar, and Azwar Iskandar. "Menuju Indonesia Berkemajuan Dalam Studi Peradaban Islam" 21, no. 1 (2021): 39-74. doi:https://doi.org/10.24042/ajsk.v21i1.7862.

Usman, Mukran H., Aswar Aswar, and Zulfiah Sam. "Covid-19 Dalam Perjalanan Akhir Zaman: Sebab, Dampak Dan Anjuran Syariat Dalam Menghadapinya." BUSTANUL FUQAHA: Jurnal Bidang Hukum Islam 1, no. 2 (2020): 137-55. doi:10.36701/bustanul.v1i2.142.

Usman, Mukran H., Azwar Iskandar, and Aswar Aswar. "Covid-19: Menguji Kebenaran Konspirasi Global.” Jurnal Studi Agama Dan Masyarakat 16, no. 2 (2021): 122-31. doi:10.23971/jsam.v16i2.2238.

Usman, Mukran H, and Aswar Aswar. "Korelasi Kehidupan Berislam Masyarakat Desa Baruga Dengan Kemakmuran, Keamanan Dan Ketentraman Hidup." Al-Din: Jurnal Dakwah Dan Sosial Keagamaan 6, no. 1 (2020): 1-14. doi:http://dx.doi.org/10.35673/ajdsk.v6i1.845. 